Journal of the Egyptian Society of Parasitology, Vol.43, No.3, December 2013

J. Egypt. Soc. Parasitol., 43(3), 2013: 755 - 766

\title{
SEROPREVALENCE OF HELICOBACTER PYLORI INFECTION AMONG FAMILY MEMBERS OF INFECTED AND NON-INFECTED SYMPTOMATIC CHILDREN
}

By

MOHAMMED E. HAMED ${ }^{1^{*}}$, HATEM M. HUSSEIN ${ }^{1}$, HOSAM F. EL SADANY ${ }^{1}$, ASHGAN A. ELGOBASHY ${ }^{1}$ AND AMAL H. ATTA ${ }^{2}$

Departments of Pediatrics ${ }^{1}$ and Microbiology ${ }^{2}$, Faculty of Medicine, Zagazig University, Egypt (Correspondance*: E-mail:mhali.love580 @gmail.com

\section{Fax. 0552593096}

\begin{abstract}
This study determined the prevalence of seropositivity of anti-H. pylori IgG antibodies, and evaluated some socio-epidemiologic characteristics among family members of infected and non-infected symptomatic children.

One hundred children with upper gastrointestinal symptoms without previous $\mathrm{H}$. pylori eradication treatment were prospectively studied by both upper endoscopy with histopathological biopsies examination, and serum anti-H. pylori IgG test between July 2012 to June 2013. The patients were subdivided into: H. pylori infected children (GI), and H. pylori non-infected children (GII). Also, 320 of their family members were examined for serum anti-H. pylori IgG and stool antigen tests. Sheets were filled out included personal and medical history.

The results showed statistically significant difference between both groups as regard dyspepsia, anemia, and histopathological findings (chronic active gastritis, peptic ulcer, and duodenitis). Family members were subdivided into: those of $H$. pylori infected symptomatic children (165) and those of $H$. pylori non-infected symptomatic children (155). Anti-H. pylori IgG prevalence was significantly higher in relatives of GI than those of GII $(69.1 \%$ vs. $29 \%$; $p<0.05)$. The seroprevalence of H.pylori infection in all family members was (49.7\%). Mothers of GI showed the highest seroprevalence $(39.5 \%)$ as compared to fathers and siblings $(22.8 \%$, \& $37.7 \%$, respectively). Relatives of GI with low socioeconomic status, and lived in rural area showed the highest seroprevalence $(82.5 \%, \& 78.1 \%$ respectively)
\end{abstract}

Keywords: Helicobacter pylori, IgG-positivity, Children, Parents, Socioepidemiology

\section{Introduction}

Helicobacter pylori is a spiral gramnegative microorganism that is distributed worldwide. It is estimated that over $50 \%$ of the world population are infected with $H$. pylori. H. pylori- associated infection is either usually clinically silent or its signs and symptoms are non-specific. Gastro-esophageal reflux, esophagitis, delayed gastric emptying, and various motility disorders are the main signs or symp- 
toms (Herbst, 2000; Go and Crowe, 2000).

The epidemiology of $H$. pylori is very complex as different factors influence the infection even within the same geographic area (Dore and Vaira, 2003). The infection is mainly acquired during childhood (Sykora et al, 2006). The prevalence is typically higher in developing countries (greater than $80 \%$ ) and lower in the developed ones (typically less than $40 \%$ ) with a declining pattern worldwide (Perez-Perez et al, 2004; Kusters et al, 2006).

The route of transmission of $H$. pylo$r i$ is not completely understood. The only known reservoir of $H$. pylori is the human stomach (Megraud and Broutet, 2000). There is evidence supporting a gastro-oral, oral-oral and fecal-oral transmission, without conclusive fixed data of the main transmission route (Azevedo et al, 2009). Person-toperson transmission can be subdivided in two main categories: vertical and horizontal transmission. The vertical family transmission spreads from ascendants to descendants, while horizontal one involves contact with individuals out-doors but does not exclude environmental role (Schwarz et al, 2008). In Egypt, Abu-Zekry et al. (2013) stated that screening for $H$. $p y$ lori infection should be performed for school-aged children who have GI complaints, especially for those who complain of recurrent abdominal pain.

Many sero-tests are available; noninvasive and invasive tests, the last ones require gastric tissue for detecting the organism and include culture, rapid urease test, histopathology, PCR, and
FISH test. Noninvasive tests include $\mathrm{H}$. pylori Ag in stool, anti $H$. pylori $\operatorname{IgG}$ in serum, urine, and oral samples, and the ${ }^{13} \mathrm{C}$-urea breath test (Guarner et al, 2010).

The present study aimed at determination of the prevalence of seropositivity of anti- $H$. pylori IgG antibodies, and evaluation of some socio-epidemiologic characters among family members of infected and non-infected symptomatic children.

\section{Patients, Materials and Methods}

This prospective study was carried out on one hundred children with upper gastrointestinal symptoms including the recurrent abdominal pain, repeated vomiting, dyspeptic symptoms, and hematemesis, admitted to the Pediatric Endoscopy and Gastroenterology Unit, Zagazig Department of Pediatrics, from July 2012 to June 2013 and their family members. All patients were subjected to full history taking, thorough clinical examination including anthropometric measurements i.e. weight, height relative to age, laboratory investigation as CBC, CRP, ESR, PT, PTT, liver function tests, routine stool, urine analysis, serum iron and ferritin by atomic absorption of Thermo 400 for those with hypochromic microcytic anemia, and serum anti-H. pylori IgG. Radiological investigations included abdominal ultrasound, and gastrographin swallow or meal when indicated. Upper GIT endoscopy was done. The patients were classified into: H. pylori infected GI, and non-infected GII. The presence of H. pylori infection was retained when histopathology examination of endoscopic biopsies and/ or anti-H. pylori 
IgG were positive. A negative result was retained when both tests were concomitantly negative.

Regarding family members, we chose who were in close contact with the patients and sharing the same living conditions, they were mothers, fathers, and siblings. They were interviewed and the following data were recorded age, sex, presence or absence of dyspeptic symptoms, geographic distribution (rural or urban), and socioeconomic class based on the scoring system of Fahmy and El-Sherbini (1983). Family members were subjected to laboratory investigations in the form of measurement of $H$. pylori $\operatorname{IgG}$ antibodies in their sera and $H$ pylori antigen in stools. The presence of $H$. pylori infection was retained when anti-H. pylori IgG and/or $H$. pylori stool antigen were positive. A negative result was retained when both tests were concomitantly negative

Exclusion criteria: Patients who were aged less than 4 years or aged over 15 years or who had any other chronic diseases or used medicines which affect the gastrointestinal system especially previous $\mathrm{H}$. pylori eradication treatment were excluded.

Histology: During upper endoscopy down to the second part of the duodenum, multiple biopsies were taken from esophagus, pyloric antrum, corpus, and duo-denum by using the Fujinon endoscope. These biopsies were fixed in $10 \%$ formaldehyde solution, stained with hematoxylin, eosin, and modified Giemsa (Alam El-Din et al, 2013). All histological sections were evaluated by the same pathologist, who was blinded to the patients' clinical conditions. An expert pathologist characterized the presence of spiral bacteria in the mucosal layer or on the surface of epithelial cells as a positive test for H. pylori.

Detection of H. pylori IgG in sera: A venous blood sample was obtained from each patient and family member. Serum specimens were tested for the presence of $\operatorname{IgG}$ antibodies against $H$. pylori using a quantitative ELISA (HEL-pTEST II; AMRAD, Kew, Australia). Reference standards were used to produce a standard curve to quantitate $H$. pylori antibody levels in patients' and their family members' samples. The results were expressed in arbitrary units per milliliter. The antigen was an inactivated native antigen of $H$. pylori. Positive results can be expressed in units $(\mathrm{U})$, interpolating the optical density values of the 5 calibrators and comparing the value of the sample with the following results: Positive results if $>16.0 \mathrm{U} / \mathrm{ml}$, Negative results if $<10.0 \mathrm{U} / \mathrm{ml}$, Equivocal if it is $10.0-16.0 \mathrm{U} / \mathrm{ml}$.

Detection of $H$. pylori antigen in stool: Immunochromatographic or rapid or quick tests were used for all family members. This method based on an immune-chromography using monoclonal antibodies (Schwarzer et al, 2007).

The study was approved by the research and ethical committee, Faculty of Medicine, Zagazig University. The parents of patients signed written consents for the contribution of them and their children in the current study. 
Statistical analysis: All data were analyzed using SPSS (version 15.0. SPSS Inc... Chicago, IL). Statistical analysis was performed using Students t-test or Mann-Whitney test, corrected $\mathrm{X}^{2}$ test or Fisher's exact Test and Spearman correlation, when appropriate. The results are expressed as counts and percentages for qualitative variables and as medians and ranges for discrete variables. A p-value $<0.05$ was considered to be statistically significant. Data are presented as the mean \pm $\mathrm{SD}$ in the tables.

\section{Results}

During the study period (100) patients were evaluated consecutively and classified into group I (50), and group II (50) according to histopathology, and serum anti-H. Pylori IgG test results, both positive and both negative respectively. $H$. pylori infected patients' ages ranged from 4 to 13 years (mean $10.24 \pm 2.16$ years old). They were $28(56 \%)$ males, and $22(44 \%)$ females. H. pylori non-infected patients' ages ranged from 6 to 12 years (mean $9.5 \pm 1.9$ years old). They were $20(40 \%)$ males, and $30(60 \%)$ females. There was no significant difference in rates of seroprevalence between boys and girls, nor for age between both groups $(\mathrm{P}>0.05)$.

A statistically significant difference between group I, and group II patients was found (Tab. 1) in relation to dyspeptic symptoms, pallor, and epigastric tenderness $(p<0.05)$, however, no statistically significant difference between both groups regarding other clinical profile $(p>0.05)$. The Seroprevalence of H.pylori infection in all studied pa- tients according to anti-H.pylori IgG was $(44+8) / 100(52 \%)$.

The significant differences between GI, and GII patients were found in relation to $\mathrm{Hb}$, serum iron, and ferritin with mean of $10.8 \pm 1.1$ vs. $11.8 \pm 0.8 \mathrm{~g} / \mathrm{dl}, 19.1$ \pm 1.72 vs. $23.3 \pm 2.88 \mu \mathrm{g} / \mathrm{dl}$, and $7.37 \pm$ 0.74 vs. $8.33 \pm 0.57 \mathrm{ng} / \mathrm{ml}$, respectively $(\mathrm{p}<0.05)$.

In the present study, showed a significant difference between GI \& GII patients regarding histopathologic results as chronic active gastritis, peptic ulcer, and duodenitis $(p<0.05)$ but, without significant difference between both groups regarding reflux oesophagitis (Tab. 2).

Validity of IgG antibodies in diagnosis of $H$. pylori infection in GI \& GII was assessed. The sensitivity, specificity, positive predictive value, negative predictive value, and accuracy were $88 \%, 84 \%, 84.6 \%, 87.5 \& 86 \%$, respectively.

Family members were evaluated consecutively for infection and subdivided into 2 groups: family members of $H$. pylori infected symptomatic patients (GI relatives $=165$ ), and family members of H. pylori non-infected symptomatic patients (GII relatives $=155$ ). Family members of GI who lived in rural area showed the highest prevalence $(72.7 \%)$, which was statistically highly significant $(p<0.001)$. Low socioeconomic class in family members of GI showed the highest prevalence (72.7\%), which was highly significant $(\mathrm{p}<0.001)$. No significant difference was among family members of GI \& GII in relation to non-ulcer dyspepsia 
including heart burn, postprandial fullness and vomiting (Tab. 3).

A highly statistically significant difference among family members of GI $\&$ GII was found in relation to serum IgG (mean 24.82 \pm 6.7 vs. $14.63 \pm 4.8 \mathrm{U} / \mathrm{ml})$, which were significantly higher prevalent in family members of GI than that of GII $(69.1 \%$ vs. $29 \%$ as $\mathrm{p}<0.05$ ). IgG antibodies showed highly significantly prevalent in mothers of GI than that of GII $(90 \%$ vs. $18 \%$ as $\mathrm{p}<0.001)$. Mothers of GI showed the highest prevalence $(39.5 \%)$ $(45 / 114)$ of IgG antibodies among other family members, which included the fathers and siblings $(22.8 \%, \& 37.7 \%)$.

Also, the fathers, and siblings of GI showed higher prevalence of IgG antibodies than those of GII ( $52 \%$ vs. $28 \%$, and $66.2 \%$ vs. $40 \%$, respectively). The highest seroprevalence of IgG antibodies $(78.1 \%)$ was found in Family members of GI who lived in rural area. Family members of GI with low socioeconomic status showed the highest seroprevalence $(82.5 \%)$ of IgG antibodies (Tab. 4).

The prevalence of $H$. pylori $\mathrm{IgG}$ in all family members was $(114+45) /$ $(165+155)(49.7 \%)$. Concordant results between the two noninvasive methods were found in 117 of $165(70.9 \%)$ relatives of GI, and 48 of $155(31 \%)$ relatives of GII (Tab. 5).

Validity of IgG antibodies in diagnosis of $H$. pylori infection in family members was assessed and the sensitivity, specificity, positive predictive value, negative predictive value, and accuracy were $80.3 \%, 81.3 \%, 82.5 \%$, $79.1 \%$, \& $80.8 \%$, respectively.

Table 1: Clinical profile and seroprevalence of anti-H. pylori IgG among groups.

\begin{tabular}{|c|c|c|c|c|c|c|}
\hline Clinical profile & \multicolumn{2}{|c|}{$\mathrm{GI}(\mathrm{N}=50)$} & \multicolumn{2}{|c|}{ G II $(\mathrm{N}=50)$} & \multirow[t]{2}{*}{$\chi^{2}$} & \multirow[t]{2}{*}{ P-value } \\
\hline Svmntoms & $\mathrm{NO}$ & $\%$ & $\mathrm{NO}$ & $\%$ & & \\
\hline Recurrent abdominal pain (RAP) & 26 & 52.0 & 23 & 46.0 & 0.36 & 0.548 \\
\hline Repeated vomiting & 20 & 40.0 & 22 & 44.0 & 0.16 & 0.685 \\
\hline Haematemesis & 10 & 20.0 & 8 & 16.0 & 0.27 & 0.60 \\
\hline Dyspeptic symptoms & 20 & 40.0 & 6 & 12.0 & 10.19 & $0.001 * *$ \\
\hline \multicolumn{7}{|l|}{ Signs } \\
\hline Pallor & 18 & 36.0 & 6 & 12.0 & 7.89 & $0.004 * *$ \\
\hline Epigastric Tenderness & 16 & 32.0 & 4 & 8.0 & 9 & $0.003 * *$ \\
\hline Periumbilical Tenderness & 26 & 52.0 & 24 & 48.0 & 0.16 & 0.689 \\
\hline weight for age $<5^{\text {th }}$ centile & 10 & 20.0 & 8 & 16.0 & 0.27 & 0.603 \\
\hline Height for age $<5^{\text {h }}$ centile & 10 & 20.0 & 8 & 16.0 & 0.27 & 0.603 \\
\hline Anti-H.Pylori $\mathrm{IgG} \mathrm{X} \pm \mathrm{SD}$ & \multirow{2}{*}{\multicolumn{2}{|c|}{$\begin{array}{l}22.3 \pm 6.7 \\
9.0-34.0\end{array}$}} & \multirow{2}{*}{\multicolumn{2}{|c|}{$\begin{array}{c}10.0 \pm 3.3 \\
7.0-17.0\end{array}$}} & $\mathrm{t}$-test & \\
\hline Range & & & & & 8.1 & $0.0001^{* *}$ \\
\hline Anti H.pylori IgG ${ }^{\text {Pos }}$ & 44 & 88 & 8 & 16 & $\chi^{2}$ & \\
\hline Anti H.pylori $\mathrm{IgG}^{\mathrm{Neg}}$ & 6 & 12 & 42 & 84 & 51.92 & $<0.001 * *$ \\
\hline
\end{tabular}

** Boldface indicate $\mathrm{p}<0.05$, Pos; positive, Neg; Negative 
Table 2: Histopathological results among groups.

\begin{tabular}{|c|c|c|c|c|c|c|}
\hline Socio-demographic characters & \multicolumn{2}{|c|}{ GI Relatives $(\mathrm{N}=165)$} & \multicolumn{2}{|c|}{ GII Relatives $(\mathrm{N}=155)$} & t-test & P-value \\
\hline \multicolumn{7}{|l|}{ Age (years) } \\
\hline $\mathrm{X} \pm \mathrm{SD}$ & \multicolumn{2}{|c|}{$32.47 \pm 8.2$} & \multicolumn{2}{|c|}{$31.90 \pm 7.4$} & 0.32 & 0.571 \\
\hline Range & \multicolumn{2}{|c|}{$6.07-48.4$} & \multicolumn{2}{|c|}{$7.1-46.7$} & & \\
\hline Gender & No & $\%$ & No & $\%$ & $x^{2}$ & \\
\hline Male & 75 & 45.5 & 70 & 45.2 & 0.00 & 0.958 \\
\hline Female & 90 & 54.5 & 85 & 54.8 & & \\
\hline Relatives & & & & & $\chi^{2}$ & \\
\hline Father & 50 & 30.3 & 50 & 32.3 & 0.14 & 0.706 \\
\hline Mother & 50 & 30.3 & 50 & 32.3 & 0.14 & 0.706 \\
\hline Sibling & 65 & 39.4 & 55 & 35.4 & 0.52 & 0.47 \\
\hline \multicolumn{7}{|l|}{ Geographic distribution } \\
\hline Rural & 120 & 72.7 & 85 & 54.8 & 11.11 & $<0.001 * *$ \\
\hline Urban & 45 & 27.3 & 70 & 45.2 & & \\
\hline Socioeconomic Class & & & & & $\chi^{2}$ & \\
\hline Low & 120 & 72.7 & 70 & 45.2 & & \\
\hline Middle & 30 & 18.2 & 61 & 39.4 & 25.51 & $<0.001 * *$ \\
\hline High & 15 & 9.1 & 24 & 15.4 & & \\
\hline Clinical profile & $\mathrm{NO}$ & $\%$ & $\mathrm{NO}$ & $\%$ & $\chi^{2}$ & P-value \\
\hline No dyspeptic symptoms & 72 & 43.7 & 80 & 51.6 & & \\
\hline Heart burn & 30 & 18.2 & 14 & 9 & & \\
\hline Postprandial fullness & 57 & 34.5 & 52 & 33.5 & 6.76 & 0.08 \\
\hline Vomiting & 6 & 3.6 & 9 & 5.9 & & \\
\hline
\end{tabular}

Table 3: Sociodemographic characters and clinical profile among family members.

\begin{tabular}{|c|c|c|c|c|c|c|}
\hline \multirow{2}{*}{$\begin{array}{l}\text { Socio-demographic } \\
\text { Age (years) }\end{array}$} & \multicolumn{2}{|c|}{ GI Relatives $(\mathrm{N}=$} & \multicolumn{2}{|c|}{ GII Relatives } & \multirow[t]{2}{*}{ t-test } & \multirow[t]{2}{*}{ P-value } \\
\hline & & & & & & \\
\hline$\times \mathrm{SD}$ & \multicolumn{2}{|c|}{$32.47 \quad 8.2$} & \multicolumn{2}{|c|}{$31.90 \quad 7.4$} & 0.32 & 0.571 \\
\hline Range & \multicolumn{2}{|c|}{$6.07-48.4$} & \multicolumn{2}{|c|}{$7.1-46.7$} & & \\
\hline Gender & No & $\%$ & No & $\%$ & $x 2$ & \\
\hline Male & 75 & 45.5 & 70 & 45.2 & 0.00 & 0.958 \\
\hline Female & 90 & 54.5 & 85 & 54.8 & & \\
\hline Relatives & & & & & $\chi^{2}$ & \\
\hline Father & 50 & 30.3 & 50 & 32.3 & 0.14 & 0.706 \\
\hline Mother & 50 & 30.3 & 50 & 32.3 & 0.14 & 0.706 \\
\hline Sibling & 65 & 39.4 & 55 & 35.4 & 0.52 & 0.47 \\
\hline \multicolumn{7}{|l|}{ Geographic distribution } \\
\hline Rural & 120 & 72.7 & 85 & 54.8 & 11.11 & $<0.001^{*}$ \\
\hline Urban & 45 & 27.3 & 70 & 45.2 & & \\
\hline \multicolumn{7}{|l|}{ Socioeconomic Class } \\
\hline Low & 120 & 72.7 & 70 & 45.2 & & \\
\hline Middle & 30 & 18.2 & 61 & 39.4 & 25.51 & $<0.001^{*}$ \\
\hline High & 15 & 9.1 & 24 & 15.4 & & \\
\hline Clinical profile & $\mathrm{NO}$ & $\%$ & NO & $\%$ & $\chi^{2}$ & P-value \\
\hline No dyspeptic symptoms & 72 & 43.7 & 80 & 51.6 & & \\
\hline Heart burn & 30 & 18.2 & 14 & 9 & & \\
\hline Postprandial & 57 & 34.5 & 52 & 33.5 & 6.76 & 0.08 \\
\hline fullness Vomiting & 6 & 3.6 & 9 & 5.9 & & \\
\hline
\end{tabular}

** Boldface indicate $\mathrm{p}<0.05$ 
Table 4: Seroprevalence of $H$. pylori among family members regards anti-IgG.

\begin{tabular}{|c|c|c|c|c|}
\hline Virulent & GI Relatives $(\mathrm{N}=165)$ & GII Relatives $(\mathrm{N}=155)$ & t-test & $\mathrm{P}$-value \\
\hline $\begin{array}{l}\text { Anti-H.pylori } \operatorname{IgG}(\mathrm{U} / \mathrm{ml}) \\
\mathrm{X} \pm \mathrm{SD} \\
\text { Range }\end{array}$ & $\begin{array}{c}24.82 \pm 6.7 \\
2.0-38.22\end{array}$ & $\begin{array}{c}14.63 \pm 4.8 \\
3.0-24.23\end{array}$ & 174.98 & $<0.001 * *$ \\
\hline $\begin{array}{l}\mathrm{IgG}^{\text {Pos }}>16 \mathrm{U} / \mathrm{mL} \\
\mathrm{IgG}^{\text {Neg }} \\
<10 \mathrm{U} / \mathrm{mL}\end{array}$ & $\begin{array}{cc}\text { No } & \% \\
114 & 69.1 \\
51 & 30.9 \\
\end{array}$ & $\begin{array}{ll}\text { No } & \% \\
45 & 29 \\
110 & 71 \\
\end{array}$ & $\begin{array}{c}\chi^{2} \\
51.3 \\
\end{array}$ & $<0.001 * *$ \\
\hline $\begin{array}{l}\text { Mothers } \\
\mathrm{IgG}^{\text {Pos }} \\
\text { IgG }^{\text {Neg }}\end{array}$ & $\begin{array}{cc}\text { No }(50) & \% \\
45 & 90 \\
5 & 10 \\
\end{array}$ & $\begin{array}{cc}\text { No }(50) & \% \\
9 & 18 \\
41 & 82 \\
\end{array}$ & 52.17 & $<0.001 * *$ \\
\hline $\begin{array}{l}\text { Fathers } \\
\text { IgG }^{\text {Pos }} \\
\text { IgG }^{\text {Neg }}\end{array}$ & $\begin{array}{ll}\text { No }(50) & \% \\
26 & 52 \\
24 & 48 \\
\end{array}$ & $\begin{array}{ll}\text { No }(50) & \% \\
14 & 28 \\
36 & 72 \\
\end{array}$ & 6 & $0.014 *$ \\
\hline $\begin{array}{l}\text { Siblings } \\
\operatorname{IgG}^{\text {Pos }} \\
\operatorname{IgG}^{\text {Neg }}\end{array}$ & $\begin{array}{cc}\text { No }(65) & \% \\
43 & 66.2 \\
22 & 33.8 \\
\end{array}$ & $\begin{array}{ll}\text { No (55) } & \% \\
22 & 40 \\
33 & 60 \\
\end{array}$ & 8.21 & $0.004 *$ \\
\hline $\begin{array}{l}\text { Geographic distribution } \\
\text { Rural } \\
\text { Urban }\end{array}$ & $\begin{array}{ll}\text { No }(114) & \% \\
89 & 78.1 \\
25 & 21.9 \\
\end{array}$ & $\begin{array}{cc}\text { No (45) } & \% \\
27 & 60 \\
18 & 40 \\
\end{array}$ & 5.34 & $0.02 *$ \\
\hline $\begin{array}{l}\text { Socioeconomic Class } \\
\text { Low } \\
\text { Middle } \\
\text { High }\end{array}$ & $\begin{array}{cc}\text { No (114) } & \% \\
94 & 82.5 \\
15 & 13.2 \\
5 & 4.3\end{array}$ & $\begin{array}{lr}\text { No (45) } & \% \\
28 & 62.2 \\
11 & 24.4 \\
6 & 13.4\end{array}$ & 7.97 & $0.019^{*}$ \\
\hline
\end{tabular}

** Boldface indicate $\mathrm{p}<0.05$, Pos ; Positive, Neg ; Negative

Table 5: H. pylori in family members of both non-invasive tests (anti-IgG \& stool antigen).

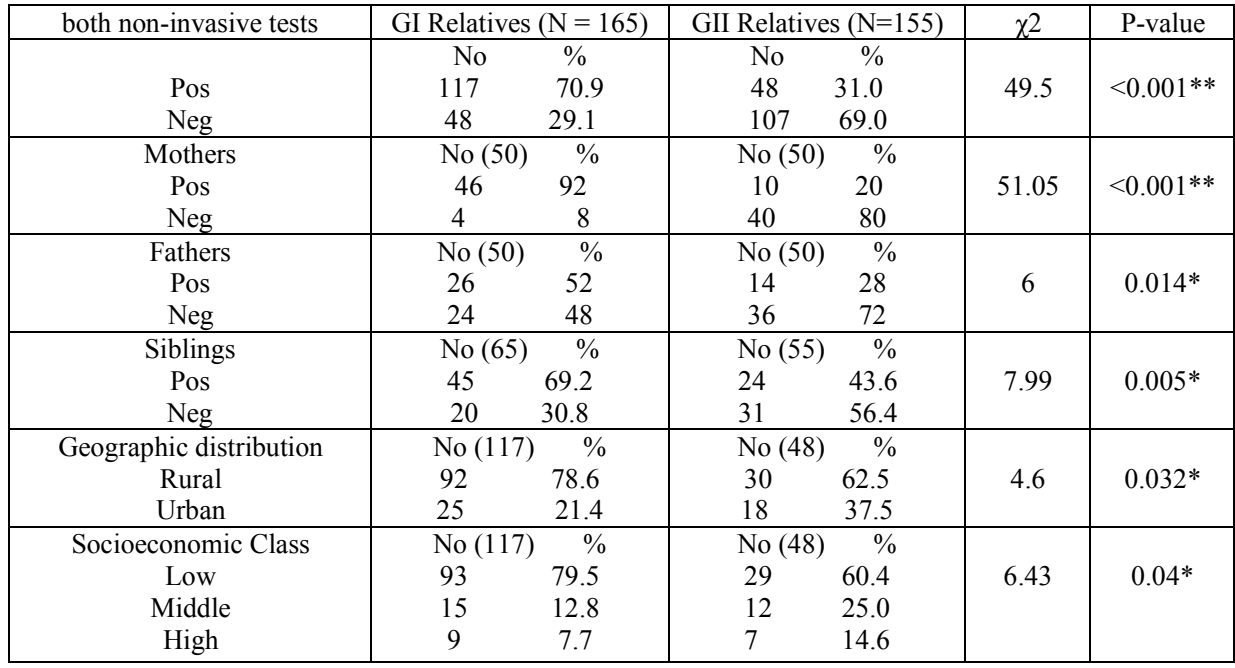

\section{Discussion}

Helicobacter pylori infection is usually acquired in early childhood. Noninvasive methods for detection of $\mathrm{H}$. pylori infection are required to study its incidence, and transmission (Konstan- topoulos et al, 2001) Serology is the noninvasive technique to detect infection because it is simple, widely available, and inexpensive. The reported sensitivity, and specificity of IgG serology is highly variable, ranging from 
$30 \%$ to $100 \%$ (Taha et al, 1993; Schembri et al, 1993), in agreement with those of our study which were $80.3 \%$, and $81.3 \%$, respectively. The present study showed seroprevalence of $H$. pylori infection of $52 \%$ among 100 children, aged $4-13$ years, in similarity with investigators from Turkey reported the seropositivity of $H$. pylori in $43.9 \%$ of 346 children aged 6 months- 16 years and in $64.4 \%$ of 466 children aged 6-17 years (Yilmaz et al, 2002; Selimoğlu et al, 2002).

In the present study, no significant association of $\mathrm{H}$. pylori infection and recurrent abdominal pain (RAP), which agreed with Spee et al. (2010) however, Mukherjee et al. (2005) reported that there is a significant association of H. pylori infection and RAP. No significant association of $\mathrm{H}$. pylori infection and hematemsis was found, in contrast to Lianes et al. (2012) who reported that haematemesis was significantly higher in $H$. pylori infected children. This may be attributed to few number of cases presented with hematemesis in our study .A significant association of H. pylori infection and dyspeptic symptoms was reported, in agreement with Babu et al. (2005) who reported that there was a statistically significant benefit of eradication of $\mathrm{H}$. pylori inpatients with ulcer-like non ulcer dyspepsia. However, Ribeiro et al. (2010) reported that there was no statistical association between dyspepsia and positive serology for $H$. pylori. A significant association of $H$. pylori infection and epigastric tenderness was found, in agreement with Yang et al. (2005) who reported that the presentation of epigas- tric pain can be considered as a warning alarm to screen for $H$. pylori infection. No significant association of $\mathrm{H}$. pylori infection and growth parameters affection was found, in agreement with Chi et al. (2009) who reported no evidence that infection with $H$. pylori is related to growth failure. But, Goodman et al. (2011) reported that chronic H. pylori infection is accompanied by slowed growth in school-age Indian children. There was a significant association of $H$. pylori infection and iron deficiency anemia, which agreed with Muhsen et al. (2010) who found that $H$. pylori was associated with higher prevalence of anemia in school-age children independently of socioeconomic variables. But, Zamani et al. (2011) did not find a significant relationship between H. pylori infection and low serum Ferritin or iron deficiency anemia.

In the present study, upper GIT endoscopy and histopathological examination showed that chronic active gastritis, peptic ulcer, and duodenitis were associated with $H$. pylori infection, which agreed with Bittencourt et al. (2006); Yakoob et al. (2010) and Genta et al. (2010). No significant relation was found between $H$. pylori and reflux oesophagitis, which agreed with Chung et al. (2011) who found that $H$. pylori positive patients were less likely to have GERD and the oesophagitis severity decreased compared to those who were $H$. pylori negative. Ali (2012) reported that $H$. pylori infection was associated with infantile colic and might be a main causative factor.

Some authors demonstrated intrafamilial clustering of $H$. pylori-associ- 
ated infection strong evidence of intrafamilial spread (Bujanover et al, 1993). The positivity of parents converted infection to their children (Zhou et al, 2000).

In the present study, Helicobacter pylori infection among family members of infected symptomatic children was significantly higher than that in non-infected symptomatic children. This finding agreed with Roma et al. (2009) who reported that the prevalence of $H$. pylori infection was significantly higher among families of infected children. The presence of at least one infected family member in all $H$. pylori-positive children suggested person to person H. pylori transmission. In the present study, mothers of infected symptomatic children showed the highest sero-prevalence of infection among all family members that agreed Weyermann et al. (2009) who reported that control for $H$. pylori status of family members was crucial for estimating the role of mothers, fathers, and siblings in the transmission of childhood H. pylori infection. In populations with low H. pylori prevalence, the infected mother was likely to be the main source for childhood infection. Also, Fialho et al. (2010) reported that the transmission of $H$. pylori occurs from infected mothers to their offspring and among siblings, notably from younger siblings to the older ones. This can be explained that infected mother mouth secretions may be the source of transmission to the infant and child. Also by using common spoons, the licking of pacifiers or teats of feeding bottles, or even for chewing or tasting children's food must be taken into consideration.

In the present study, siblings of infected symptomatic children showed (66.2\%) sero-positive. Drumm et al. (1990) found seropositivity up to $80 \%$ of siblings of children colonized with $H$. pylori compared to $13 \%$ of agematched controls.

The fathers' of infected symptomatic children was positive in $52 \%$, which was lower than $86 \%$ reported by Escobar et al. (2004).

As infected children and their family members were in close contact, and shared in the same environmental factors, our study showed the highest seroprevalence of $H$. pylori infection was in family members of infected children with low socioeconomic class, and those lived in rural areas. Páez Valery et al. (2006) reported high prevalent among socially and economically deprived children, and poor housing conditions. Also, Etukudo et al. (2012) reported that $H$. pylori infection in Nigerian children was high and associated with low social class, poor domestic water and poor sanitation. Improvement of water supply, human and domestic waste disposal systems and ultimately poverty alleviation would control this bacterial infection that has severe long term consequences.

The present overall higher rate of infection in family members of infected children lived in a rural area was $78.1 \%$ than in an urban area $(21.9 \%)$. However, Ceylan et al. (2007) reported that infection in an urban population $(25.8 \%)$ than in a rural population 
(10.2\%), which may be attributed to environmental and habitual conditions

\section{Conclusion}

The seroprevalence of $H$. pylori infection is significantly higher among family members of infected symptomatic children. Infected family members, especially mothers, have an important role of transmission of H. pylo$r i$ within families. All children having any upper gastrointestinal complaints should be tested for infection and whether $H$. pylori was prevalent among their family members. Low socioeconomic status, and/or living in rural area are major risk factors for a higher prevalence of $H$. pylori infection.

\section{References}

Abu-Zekry, MA, Hashem, M, Ali, AA, Mohamed, IS, 2013: Frequency of gastrointestinal manifestations. Egypt. Publ. Hlth. Assoc. 88, 2:74-8.

Alam El-Din, HM, Hashem, AG, Ragab, YM, Hussein, IL, Mohamed, DB, et al, 2013: Evaluation of noninvasive versus invasive techniques for the diagnosis of Helicobacter pylori infection. Appl. Immunohistochem. Mol. Morphol. 21, 4:326-33.

Ali, AM, 2012: Helicobacter pylori and infantile colic. Arch. Pediatr. Adolesc. Med. 166, 7:648-50.

Azevedo, NF, Huntington, J, Goodman, KJ, 2009: The epidemiology of Helicobacter pylori and public health implications. Helicobacter 14, 1:1-7.

Babu, V, Kate, V, Ananthakrishnan, N, 2005: Role of eradication of Cag A Helicobacter pylori in non ulcer dyspepsia. Trop. Gastroenterol. 26, 4:2114.
Bittencourt, PF, Rocha, GA, Penna, FJ, Queiroz, DM, 2006: Gastroduodenal peptic ulcer and Helicobacter pylori infection in children and adolescents. J. Pediatr. 82, 5:325-34.

Bujanover, Y, Reif, S, Yahav, J, 1996: Helicobacter pylori and peptic disease in the pediatric patient. Pediatr. Clin. North Am. 143:213-34.

Ceylan, A, Kurımi, E, Tuncer, O, Türkdoğan, K, Sevil-Arıyuca, S, et al, 2007: Prevalence of Helicobacter pylori in children and their family members in a district in Turkey. J. Hlth. Popul. Nutr. 25, 4:422-7.

Chi, H, Bair, MJ, Wu, MS, Chiu, NC, Hsiao, YC, et al, 2009: Prevalence of Helicobacter pylori infection in high-school students on Lanyu Island, Taiwan: Risk factor analysis and effect on growth. J. Formos. Med. Assoc. 108, 12:929-36.

Chung, SJ, Lim, SH, Choi, J, Kim, D, Kim, YS, et al, 2011: Helicobacter pylo-ri serology inversely correlated with the risk and severity of reflux esophagitis in Helicobacter pylori endemic area: A matched case-control study of 5,616 health check-up Koreans. J. Neurogastroenterol. Motil. 17:267-73.

Dore, MP, Vaira, D, 2003: Sheep rearing and Helicobacter pylori infectionan epidemiological model of anthropozoonosis. Dig. Liver Dis. 35, 1:7-9. Drumm, B, Perez-Perez, GI, Blaser, MJ, Sherman, PM, 1990: Intra-familial clustering of Helicobacter pylori infection. N. Engl. J. Med. 322:359-63. Escobar, ML, Kawakami, E, 2004: Evidence of mother-child transmission 
of Helicobacter pylori infection. Arq. Gastroenterol. 4:239-44.

Etukudo, OM, Ikpeme, EE, Ekanem, EE, 2012: Seroepidemiology of Helicobacter pylori infection among children seen in a tertiary hospital in Uyo, southern Nigeria. Pan Afri. Med. J. 12:39-44.

Fahmy, SI, El-Sherbini, AF, 1983: Determining simple parameters for social classification for health research. Bull. High Inst. Pub. Hlth. 13: 95-107.

Fialho, AM, Braga, AB, Braga, MB, Carneiro, JG, Rocha, AM, et al, 2010: Younger siblings play a major role in Helicobacter pylori transmission among children from a lowincome community in the Northeast of Brazil. Helicobacter 15, 6:491-6.

Genta, RM, Kinsey, RS, Singhal, A, Suterwala, S, 2010: Gastric foveolar meta-plasia and gastric heterotopia in the duodenum: no evidence of an etiologic role for Helicobacter pylori. Hum. Pathol. 41, 11:1593-600.

Go, MF, Crowe, SE, 2000: Virulence and pathogenicity of Helicobacter pylori. Gastroenterol. Clin. North Am. J. 29:64-70.

Goodman, KJ, Correa, P, Mera, R, Yepez, MC, Cerón, C, et al, 2011: Effect of Helicobacter pylori infection on growth velocity of school-age Andean children. Epidemiol. 22, 1:11826.

Guarner, J, Kalach, N, Elitsur, Y, et al, 2010: Helicobacter pylori diagnostic tests in children: review of the literature from 1999 to 2009. Eur. J. Pediatr. 169: 1525-32.

Herbst, JJ, 2000: Ulcer disease. In: Nelson Textbook of Pediatrics. Beh- rman, RE, Kliegman, RM, Jenson, HB (eds). $16^{\text {th }}$ ed. Philadelphia: Saunders.

Konstantopoulos, N, Rüssmann, H, Tasch, C, Sauerwald, T, Demmelmair, H, et al, 2001: Evaluation of the Helicobacter pylori stool antigen test (HpSA) for detection of Helicobacter pylori infection in children. Am. J. Gastroenterol. 96, 3: 677-83.

Kusters, JG, van Vliet, AH, Kuipers, EJ, 2006: Pathogenesis of Helicobacter pylori infection. Clin. Microbiol. Rev. 19, 3:449-60.

Lianes, R, Millán, LM, Escobar, MP, Gala, A, Capó, V, et al, 2012: Low prevalence of Helicobacter pylori among symptomatic children from a hospital in Havana, Cuba. J. Trop. Pediatr. 58, 3:231-4

Megraud, F, Broutet, N, 2000: Review article: have we found the source of Helicobacter pylori? Aliment. Pharmacol. Ther. 14, 3:7-12.

Muhsen, K, Barak, M, Henig, C, Alpert, G, Ornoy, A, et al, 2010: Is the association between Helicobacter pylori infection and anemia age dependent? Helicobacter 15, 5:467-72.

Mukherjee P, Chacko B, Singh T, Pawar G, Kaur H. Prevalence of Helicobacter pylori infection in children with recurrent abdominal pain. Trop Gastroenterol. 2005 ;26:102-4.

Páez-Valery, MC, Barón, MA, Solano, L, Nadaff, G, Boccio, J, et al, 2006: Helicobacter pylori infection $\left({ }^{13} \mathrm{C}-\mathrm{UBT}\right)$, and its relationship with nutritional and socioeconomic factors in low income school children from Valencia, Venezuela. Arch. Latinoam. Nutr. 56, 4:342-9.

Perez-Perez, GI, Rothenbacher, D, 
Brenner, H, 2004: Epidemiology of Helicobacter pylori infection. Helicobacter 9:1-6.

Ribeiro, RB, Martins, HS, Dos Santos, VA, El Khouri, M, Duarte, LS, et al, 2010: Evaluation of Helicobacter pylori colonization by serologic test (IgG) and dyspepsia in volunteers from the countryside of Monte Negro, in the Brazilian western Amazon region. Rev. Inst. Med. Trop. Sao Paulo 52, 4:203-6. Roma, E, Panayiotou, J, Pachoula, J, Kafritsa, Y, Constantinidou, C, et al, 2009: Intra-familial spread of Helicobacter pylori infection in Greece. J. Clin. Gas-troenterol. 43, 8:711-5.

Schembri, MA, Lin, SK, Lambert, JR, 1993: Comparison of commercial diagnostic tests for Helicobacter pylori antibodies. J. Clin. Micobiol. 31:26214.

Schwarz, S, Morelli, G, Kusecek, B, Manica, A, Balloux, F, et al, 2008: Horizontal versus Familial Transmission of Helicobacter pylori. PLoS Pathog. 4, 10: e1000180.

Schwarzer, A, Lottspeich, C, Russmann, H, et al, 2007: Evaluation of a novel rapid one-step monoclonal chromatographic immunoassay for detection of Helicobacter pylori in stool from children. Eur J Clin Microbiol Infect Dis 26:475-80

Selimoğlu, MA, Ertekin, V, Inandi, T, 2002: Seroepidemiology of Helicobacter pylori infection in children living in eastern Turkey. Pediatr. Int. 44: 666-9.

Spee, LA, Madderom, MB, Pijpers, M, van Leeuwen, Y, Berger, MY, 2010: Association between $H$. pylori and gastrointestinal symptoms in child- ren. Pediatr. 125, 3:E651-69.

Sykora, J, Pazdiora, P, Varvarovska, J, et al, 2006: Current epidemiological and clinical issues regarding Helicobacter pylori infection in childhood. Epidem. Mikrobiol. Immu. 55, 1:3-16. Taha, AR, Reid, J, Boothman, P, et al, 1993: Serological diagnosis of $\mathrm{Hel}$ icobacter pylori evaluation of four tests in presence or absence of non-steroidal anti-inflammatory drugs. Gut 34:461-5. Weyermann, M, Rothenbacher, D, Brenner, H, 2009: Acquisition of $\mathrm{He}$ licobacter pylori infection in early childhood: independent contributions of infected mothers, fathers, and siblings. Am. J. Gastroenterol. 104, 1:182-9.

Yakoob, MY, Hussainy, AS, 2010: Chronic gastritis and Helicobacter pylori: a histopathological study of gastric mucosal biopsies. J. Coll. Physic. Surg. Pak. 20, 11:773-5.

Yang, YJ, Sheu, BS, Lee, SC, Wu, JJ, 2005: Short term recurrent abdominal pain related to Helicobacter $p y$ lori infection in children. J. Gastroenterol. Hepatol. 20, 3:395-400.

Yilmaz, E, Dogan, Y, Gürgöze, MK, Ünal, S, 2002: Seroprevalence of Helicobacter pylori infection among children and their parents in eastern Turkey. J. Paediatr. Child Hlth. 38:183-6.

Zamani, A, Shariat, M, Yazdi, ZO, Bahrem, S, Asbagh, PA, et al, 2001: Relationship between Helicobacter pylori infection and serum ferritin level in primary school children of TehranIran. J. Pak. Med. Assoc. 61, 7:658-61.

Zhou, H, Chan, KL, Chu, K, Tam, P, 2000: Intra-familial spread of $H$. pylo$r i$ : a prospective study using urea breath test. J. Pediatr. Surg. 35, 11:1672-6 